\title{
Choice of resin cement shades for a high- translucency zirconia product to mask dark, discolored or metal substrates
}

\author{
Shiqi Dai ${ }^{1+}$, Chen Chen ${ }^{2+}$, Mo Tang ${ }^{1}$, Ying Chen ${ }^{1}$, Lu Yang${ }^{1}$, Feng He${ }^{1}$, Bingzhuo Chen ${ }^{1}$, Haifeng Xie ${ }^{1 *}$ \\ 'Jiangsu Key Laboratory of Oral Diseases; Department of Prosthodontics, Affiliated Hospital of Stomatology, Nanjing Medical \\ University, Nanjing, China \\ ${ }_{2}^{2}$ Jiangsu Key Laboratory of Oral Diseases; Department of Endodontics, Affiliated Hospital of Stomatology, Nanjing Medical \\ University, Nanjing, China
}

\begin{abstract}
PURPOSE. The aim was to study the masking ability of high-translucency monolithic zirconia and provide guidance in selecting resin luting cements in order to mask discolored substrates. MATERIALS AND METHODS. 160 high-translucency zirconia specimens were divided into 32 groups depending on their thickness and shades. Using five shades of try-in paste, the specimens were luted onto the substrates (Co-Cr, precious-metal, opaque porcelain-sintered Co-Cr, opaque porcelain-sintered precious-metal, and 5M3-shade zirconia). All CIELAB color parameters were measured and statistically analyzed. RESULTS. Zirconia shade and thickness and try-in paste shade affected CIELAB color parameters $(P=.000)$ in different substrates groups, and there were interactions among these factors $(P=.000)$. All five try-in paste shades can be chosen to achieve $\Delta \mathrm{E}$ values of zirconia with 1.2 - $1.5 \mathrm{~mm}$ for masking dark-tooth-like 5M3-shade and zirconia with $1.5 \mathrm{~mm}$ for masking precious-metal groups < 2.6. Only suitable try-in paste shades were used, can $\Delta \mathrm{E}$ values that less than 2.6 be achieved when applied translucent monolithic zirconia with 0.7-1.0 mm for masking dark-tooth-like 5M3-shade and zirconia with 0.7 $1.2 \mathrm{~mm}$ for masking precious-metal groups. CONCLUSION. Choosing suitable resin cement shades is necessary for high-translucency monolithic zirconia to achieve ideal masking ability $(\Delta \mathrm{E}<2.6)$ on the dark-tooth. [J Adv
\end{abstract}

Prosthodont 2019;11:286-96]

KEYWORDS: Resin cement; Color; Zirconia; Post-core; Spectrophotometry

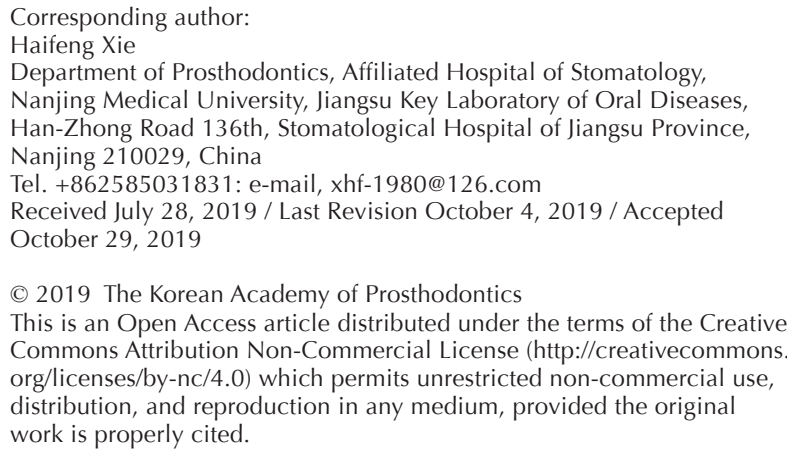

†These authors contributed equally to this work.

This work was supported by the National Natural Science Foundation of China [grant number 81970927]; the Natural Science Foundation of Jiangsu Province [grant number BK20191348]; the National Key Research and Development Program of China [grant number 2016YFA0201704]; the Jiangsu Higher Education Institutions [grant number 2018-87]; and QingLan Project.

\section{INTRODUCTION}

Zirconia-based ceramics have become increasingly popular in dental restorations due to their good esthetic characteristics $^{1}$ and excellent mechanical and biological properties. ${ }^{2}$ However, traditional zirconia has a lower and more opaque refractive index than dentin (16.4 for $1.0 \mathrm{~mm}$ ), enamel (18.7 for $1.0 \mathrm{~mm}),{ }^{3}$ silica-based ceramic and resin composites. ${ }^{4,5}$ Veneering porcelains are therefore used to cover the zirconia core in order to achieve natural shade in restoration. ${ }^{2}$ However, veneer chipping ${ }^{6}$ and delamination ${ }^{7}$ remain the main drawbacks of double-layer zirconia-based restoration because veneering feldspathic porcelains and zirconia substructures have different thermal expansion coefficients. ${ }^{8}$ In addition, veneering porcelains need greater tooth reduction. Restoration using high-translucency monolithic zirconia, which allows light to pass through with less scattering, ${ }^{2,9}$ has therefore been developed.

Monolithic traditional zirconia with low translucency has 
been used to restore metal post-core or discolored teeth. ${ }^{10}$ An increase in translucency, however, decreases the zirconia's masking ability, which, in turn, leads to the potential problem of the discolored inner tooth structure or postcore being reflected. ${ }^{11}$ Tabatabaian $e t$ al. ${ }^{12}$ found that nonprecious metal post-core have a significantly negative effect on the final color of zirconia-based restoration when the ceramic thickness is $0.5 \mathrm{~mm}$, even though the zirconia investigated in their study was low-translucency. In clinical restorations, the recommended range of thickness for monolithic zirconia is $0.5-2.0 \mathrm{~mm} .{ }^{13}$ It has also been found that 0.5 -mm low-translucency zirconia ceramic could not mask tooth discoloration. ${ }^{14}$ An increase in thickness improves the masking ability of translucent zirconia. ${ }^{15}$ Nevertheless, Suputtamongkol et al. ${ }^{16}$ demonstrated in a clinical trial that when luted onto a metal post-core, translucent zirconia crowns of $<1.5 \mathrm{~mm}$ thickness would still not match the color of natural teeth. Some authors have suggested sintering a layer of opaque porcelain onto a post-core to reduce the negative effect of metal-substrate color in high-translucency glass-based ceramic restorations, ${ }^{17}$ but even this procedure resulted in a darker and bluer final color. ${ }^{18}$ High-translucency zirconia achieves better masking ability than does glassbased ceramic, ${ }^{19}$ but whether this improved masking ability would lead to better esthetic outcomes if the post-core is opaque porcelain-sintered metal remains unknown.

Based on a previous study ${ }^{20}$ the minimum thickness of high-translucency zirconia should be at least $4.0 \mathrm{~mm}$ to totally mask the substrate, but tooth preparation poses obvious limitations on increasing ceramic-layer thickness. Fortunately, different shades of luting cements have been developed that, when used with highly translucent ceramic, are better able to mask metal post-core or discolored teeth. ${ }^{21}$ Resin cement is preferred to bond zirconia-based ceramic restoration due to its strong adhesion, good sealing properties, color, and insolubilization. ${ }^{22}$ Previous studies have analyzed the effects of resin cement shades on glassbased ceramic restorations ${ }^{23,24}$ and recommended changing those shades to improve final esthetic outcomes. ${ }^{25,26}$ Unfortunately, studies focusing on how the choice of resin cement shade affects the esthetic quality of high-translucency monolithic-zirconia restoration are rare. The final esthetic outcomes of such restorations on discolored teeth or a metal post-core partly depend on experience, instead of an established strategy for choosing an appropriate shade of resin cement. Technique sensitivity makes these outcomes uncontrollable and unpredictable.

Lava Plus Zirconia (Lava Plus High Translucency, 3M ESPE, Maplewood, MN, USA) is a novel product introduced to market in recent years; it is popular due to its advantages of strength as high as $1200 \mathrm{MPa}$, high translucency (total light transmittance $44.12 \%$ ) and a warm and natural esthetic appearance. According to the manufacturer, at a high-speed sintering cycle, it sinters to a highly dense polycrystalline microstructure with an average grain size of $<0.5 \mu \mathrm{m}$; moreover, its strength and toughness allow it to be used at a minimum thickness of $0.5 \mathrm{~mm}$. However, limit- ed information is available on the choice of resin cement shade and the minimal ceramic thickness of Lava Plus Zirconia required to mask discolored substrates because this product was introduced recently.

Therefore, we designed this study to evaluate Lava Plus Zirconia's masking ability at different thicknesses and in different shades, and against metal post-core and darkly discolored teeth, when different shades of luting media were applied. The goal was to offer guidance in selecting a resin cement for luting high-translucency monolithic zirconia onto discolored substrates of dark teeth or metal post-cores with or without sintering a layer of opaque porcelain. The null hypotheses were as follows: (a) the final colors of Lava Plus Zirconia would not be affected by the thickness or shade of zirconia or by substrate color; and (b) changing shades of resin cement for luting Lava Plus Zirconia would not achieve a clinically acceptable color difference to mask differently discolored substrates.

\section{MATERIALS AND METHODS}

We fabricated 160 Lava Plus high-translucency zirconia specimens $(15.0 \mathrm{~mm} \times 15.0 \mathrm{~mm})$ using a low-speed cutting machine (IsoMet 1000, Buehler, Lake Bluff, IL, USA) and divided them into 32 groups $(n=5)$ depending on their thickness and color.

Before sintering, we calculated the thicknesses of the specimens according to a linear-shrinkage ratio of $25 \%$, so that final thicknesses were 0.7, 1.0, 1.2, and $1.5 \mathrm{~mm}$. Every thickness was divided into eight subgroups, to be dyed with 1M1, 1M2, 2M1, 2M2, 2M3, 3M2, 4M2, or 5M2 shade dyeing liquid (Lava Plus HT ZR Dyeing Liquid, 3M ESPE, Maplewood, MN, USA) to simulate different shades of zirconia restorations.

We sintered the Lava Plus specimens per manufacturer's instructions and wet-polished them using a metallographic polishing machine (PG-1, Shanghai Standard Precision Instrument Co. Ltd., Shanghai, China) with grit sizes of 600, 800,1200 , and 1600 in that order. Final specimen thicknesses were verified as $0.7,1.0,1.2$, and $1.5 \mathrm{~mm}$ with a vernier caliper (accurate to $\pm 0.02 \mathrm{~mm}$; Nanjing Su Measuring Instrument Co. Ltd., Nanjing, China). Subsequently, one side of each specimen was air abraded with $50-\mu \mathrm{m}$ alumina, cleaned ultrasonically and air dried. Supplemental Fig. 1 presents the masking ability of the prepared Lava Plus high-translucency zirconia specimens in different thicknesses and shades on the black background.

Two pieces of cobalt-chrome (Co-Cr) alloy (Wirobond C, Bego GmbH \& Co. KG, Bremen, Germany) and two pieces of precious-metal substrates $(75 \% \mathrm{Au}, 8.6 \% \mathrm{Pt}$; BioUniversal PKF, Ivoclar Vivadent AG, Schaan, Liechtenstein) of $8.0 \mathrm{~mm}$ $\times 8.0 \mathrm{~mm} \times 1.0 \mathrm{~mm}$ in size were casted to simulate metal post-cores. One piece of each kind was sintered with a layer of opaque porcelain about $0.3 \mathrm{~mm}$ thick (2M2 shades; Shofu Inc., Kyoto, Japan).

Using the aforementioned methods, nine $10.0 \mathrm{~mm} \times$ $10.0 \mathrm{~mm} \times 5.0 \mathrm{~mm}$ zirconia blocks in shades of $1 \mathrm{M} 1,1 \mathrm{M} 2$, 

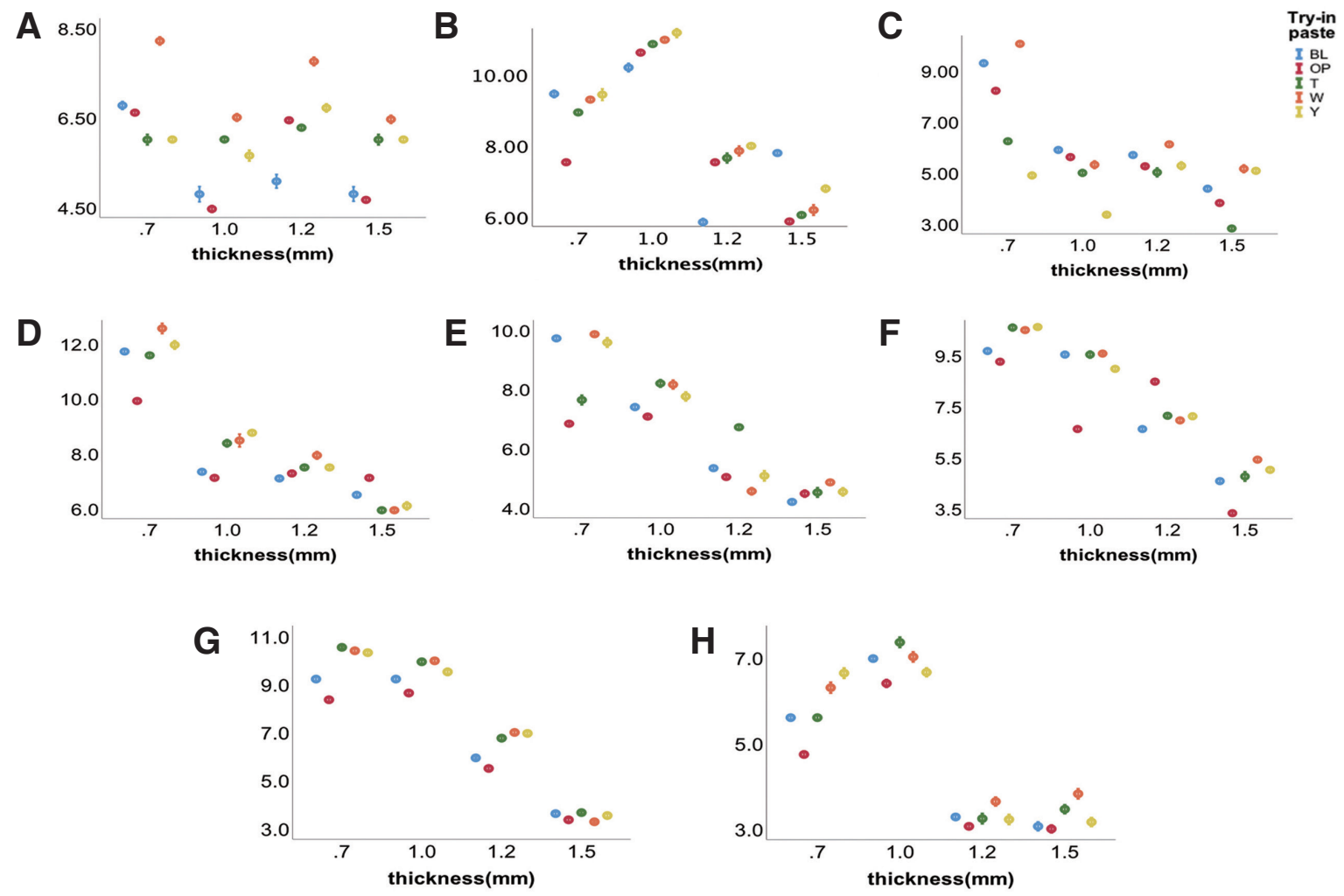

Fig. 1. Means and standard deviations of $\Delta \mathrm{E}$ values for $\mathrm{Co}-\mathrm{Cr}$ alloy substrate groups. Groups of zirconia in $1 \mathrm{M} 1$ shade (A), $1 M 2$ shade $(B), 2 M 1$ shade $(C), 2 M 2$ shade $(D), 2 M 3$ shade $(E), 3 M 2$ shade $(F)$, $4 M 2$ shade $(G)$ and $5 M 2$ shade $(H)$.

A

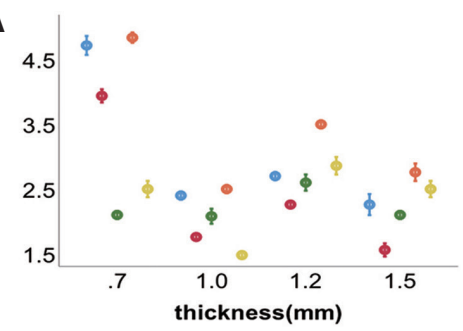

D

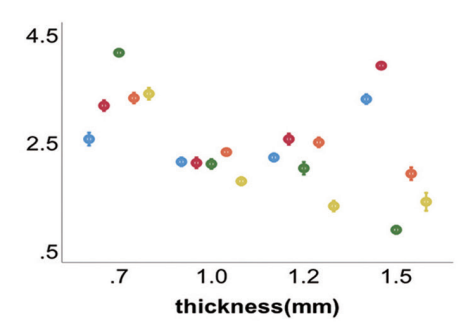

B

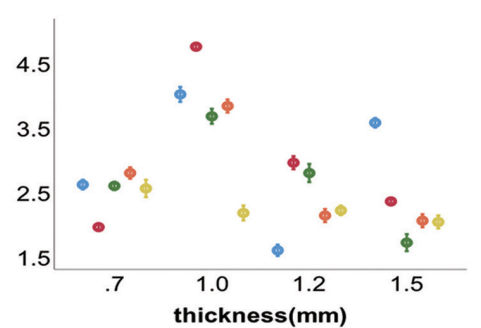

E

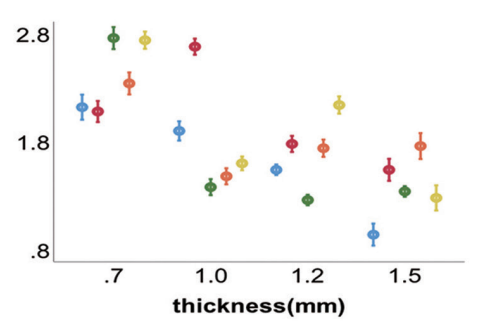

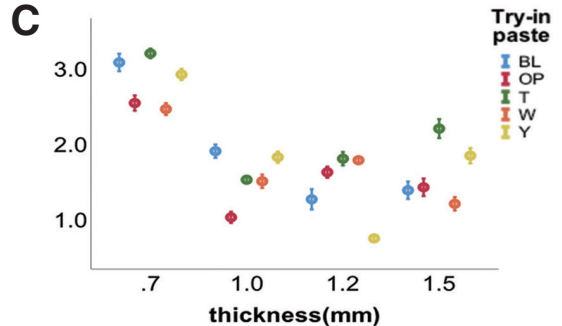

$\mathbf{F}$

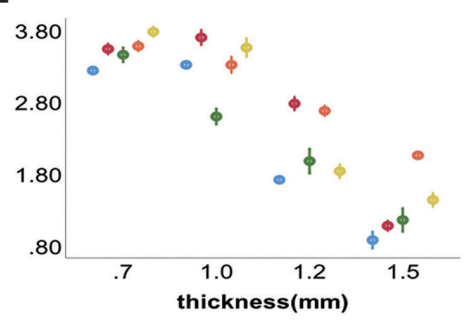

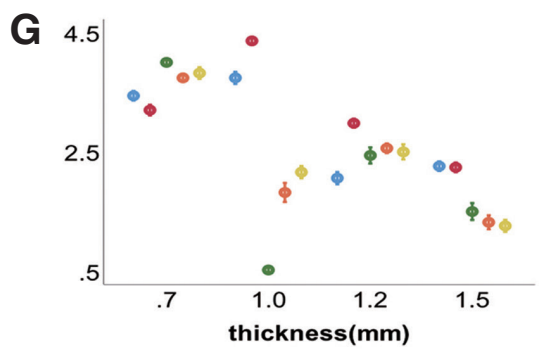

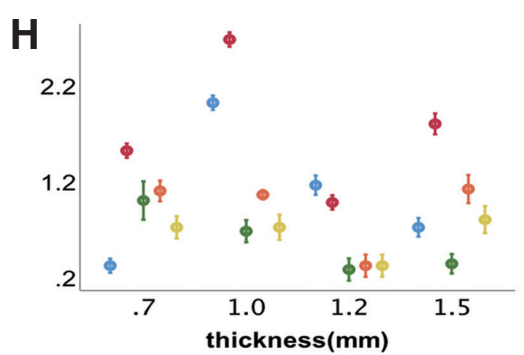

Fig. 2. Means and standard deviations of $\Delta \mathrm{E}$ values for precious-metal substrate groups. Groups of zirconia in $1 \mathrm{M} 1$ shade (A), $1 M 2$ shade (B), $2 M 1$ shade (C), 2M2 shade (D), $2 M 3$ shade $(E), 3 M 2$ shade $(F)$, 4M2 shade $(G)$ and $5 M 2$ shade $(H)$. 
2M1, 2M2, 2M3, 3M2, 4M2, 5M2, and 5M3 were sintered. The 5M3-shade zirconia block was intended to simulate the color of dark teeth. Supplemental Fig. 2 presents the prepared substrates made by zirconia blocks in different shades and metal. Each shade and thickness of Lava Plus specimen was luted onto (a) a 5.0-mm-thick zirconia block of the same shade, (b) the 5M3-shade zirconia block simulating dark teeth, (c) Co-Cr alloy, (d) opaque porcelain-sintered Co-Cr alloy, (e) precious-metal and (f) opaque porcelain-sintered precious-metal. Luting was done using try-in pastes (Variolink N; Ivoclar Vivadent AG, Schaan, Liechtenstein) in shades of "white," "yellow," "transparent," "bleach," or "opaque." The force of $5 \mathrm{~N}$ was added on the sample for 10 $\mathrm{s}$ and excessive try-in paste was removed. We classified the groups by shade and thickness of zirconia, shade of try-in paste, and color of substrate.

Dental colorimeter (ShadeEye NCC, Shofu Inc., Koyto, Japan) was used to measure color parameters based on the CIELAB color system (L*: lightness; $a^{*}$ : redness-greenness; $\mathrm{b}^{*}$ : yellowness-blueness) recommended by the International Commission on Illumination (CIE). ${ }^{27}$ All specimens were measured against a white background ( $L^{*}: 96.5 ; a^{*}:-0.5$; $b^{*}$ : 1.2). The measuring head of the dental colorimeter was placed perpendicularly against the center of each specimen surface. CIELAB color parameters were measured 3 consecutive times per specimen; an average of 3 readings was calculated and recorded. The dental colorimeter was recalibrated after every 5 readings. Whenever the shade of try-in paste was changed, the surfaces of the zirconia specimens and substrates were first washed with water, cleaned them ultrasonically with ethanol for 10 minutes, and then air dried them.

The color differences $(\Delta \mathrm{E})$ of the 3-layered (zirconia/ try-in paste/substrate) specimens in each group were calculated as follows:

$$
\Delta E=\left[(\Delta L *)^{2}+(\Delta a *)^{2}+(\Delta b *)^{2}\right]^{1 / 2},
$$

where the original color parameters of each 3-layered specimen were those of the zirconia specimen in one shade at the thickness under investigation, luted onto a $5.0-\mathrm{mm}$ thick zirconia block of the same shade with the "transparent" shade of try-in paste. According to a recent review, the 1976 $\Delta \mathrm{E}$ formula is still one of widely used formula to evaluate the color match between a restoration and adjacent teeth or a target color. ${ }^{28}$ Based on a previous research, ${ }^{29-31} \Delta \mathrm{E}$ values less than 5.5 were regarded as clinically acceptable and $\Delta \mathrm{E}$ values less than 2.6 were regarded as not perceptible.

Data were analyzed using SPSS statistical software version 25 (IBM SPSS Statistics v25, IBM Corp., Chicago, IL, USA). For each substrate, we subjected data to Box's and Leneve's tests to evaluate homogeneity of variance, comparing differences in CIELAB parameter values; data that passed these tests were then subjected to multivariate analysis of variance (MANOVA) and least-significant-difference (LSD) tests. We also performed one-way ANOVA and LSD tests to compare the $\Delta \mathrm{E}$ values of different groups within each substrate, as well as to determine the effects of try-in paste shade on the $\Delta \mathrm{E}$ value of each shade and thickness of zirconia to mask the same substrate. $P=.05$ was considered statistically significant for all analyses.

\section{RESULTS}

Mean $\Delta \mathrm{E}$ values and their standard deviations (SD) for all groups are shown in Fig. 1 - Fig. 5. According to the MANOVA and LSD tests, color and thickness of zirconia specimens and shade of try-in paste affected CIELAB color parameters $(P=.000)$ for different substrates, and there were interactions among these factors $(P=.000)$. All $P$ values are listed in Supplemental Table 1.

On discolored substrates, simulated by the 5M3 shade, $\Delta \mathrm{E}$ values for all 8 shades of $0.7-1.5 \mathrm{~mm}$ Lava Plus zirconia specimens were $<5.5$, no matter which shade of try-in paste was chosen. $\Delta \mathrm{E}$ values for all 8 shades of $1.2-1.5$ $\mathrm{mm}$ specimens were $<2.6$, no matter which shade of try-in paste was chosen. Suitable try-in paste shades should be chosen to achieve $<2.6 \Delta \mathrm{E}$ values of zirconia with $0.7-1.0$ $\mathrm{mm}$ for masking discolored substrates. Choosing the "transparent" shade of try-in paste reduced $\Delta \mathrm{E}$ values to $<2$.6. $\Delta \mathrm{E}$ values of 6 shades of zirconia specimens (excepting $1 \mathrm{M} 1$ and 4M2) with $0.7-1.5 \mathrm{~mm}$ thickness were $<2.6$ when we used the "transparent," "white," or "yellow" shade of try-in paste. $\Delta \mathrm{E}$ values of $1 \mathrm{M} 1$-shade specimens of 1.0$1.5 \mathrm{~mm}$ thickness were $<2.6$ on $5 \mathrm{M} 3$-shade substrate, no matter which shade of try-in paste was used; when zirconia thickness was $0.7 \mathrm{~mm}$, however, only the "transparent" and "yellow" shades of try-in paste yielded $\Delta \mathrm{E}$ values $<2.6$. Similarly, $\Delta \mathrm{E}$ values of $4 \mathrm{M} 2$-shade specimens of $1.2-1.5$ $\mathrm{mm}$ thickness were $<2.6$, regardless of try-in paste shade; but, when specimens were $0.7-1.0 \mathrm{~mm}$ thick, only the "transparent," "opaque," and "bleach" shades of try-in paste yielded $\Delta \mathrm{E}$ values $<2.6$.

On the Co-Cr alloy substrate, no zirconia specimen of $0.7-1.5 \mathrm{~mm}$ thickness in any of the 8 shades could achieve $\Delta \mathrm{E}$ values $<2.6$, no matter which shade of try-in paste was used. Moreover, $\Delta \mathrm{E}$ values of most of the 8 shades on the Co-Cr alloy post-core exceeded 5.5 when zirconia thickness was $0.7-1.0 \mathrm{~mm}$. For the $1 \mathrm{M} 2$ and $2 \mathrm{M} 2$ shades, even when ceramic thickness reached $1.5 \mathrm{~mm}$, we could not reduce the $\Delta \mathrm{E}$ value of any try-in paste to $<5.5$. Fortunately, the other 6 shades of $1.5-\mathrm{mm}$ zirconia specimen yielded $\Delta \mathrm{E}$ values $<$ 5.5 when we used the opaque or bleach shade of try-in paste.

Sintering opaque porcelain to the Co-Cr alloy reduced $\Delta \mathrm{E}$ values of all 8 shades of Lava Plus high-translucency zirconia. When suitable shades of try-in paste were used, $1.5 \mathrm{~mm}$ thick zirconia in 7 shades (except 1M1) yielded $\Delta \mathrm{E}$ values $<2.6$. No matter which shade of try-in paste was chosen, $1.2-1.5 \mathrm{~mm}$ thick zirconia specimens in all 8 shades resulted in $\Delta \mathrm{E}$ values $<5.5$. When thickness was 1.0 $\mathrm{mm}$, all zirconia specimens except those in $1 \mathrm{M} 1$ shade could yield $\Delta \mathrm{E}$ values $<5.5$. Zirconia specimens in $4 \mathrm{M} 2$ shade could even achieve $\Delta \mathrm{E}$ values of $<2.6$, no matter 
A

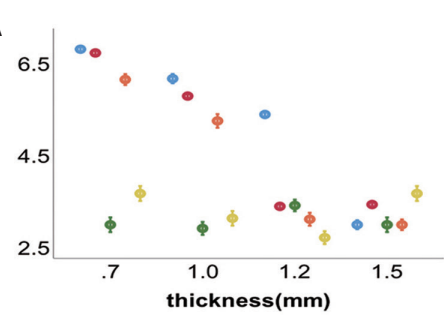

D

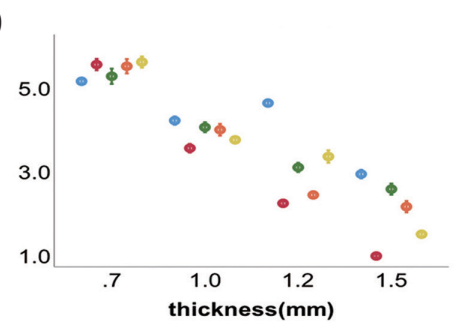

B

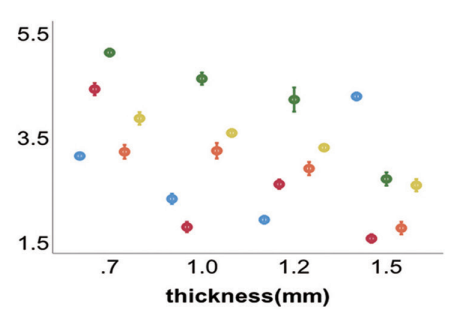

E

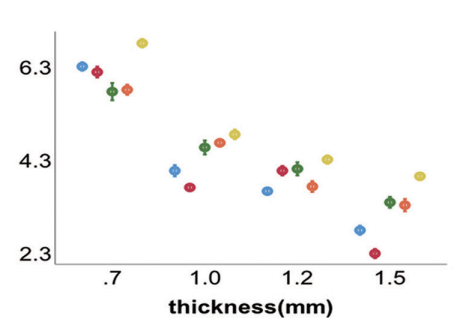

C

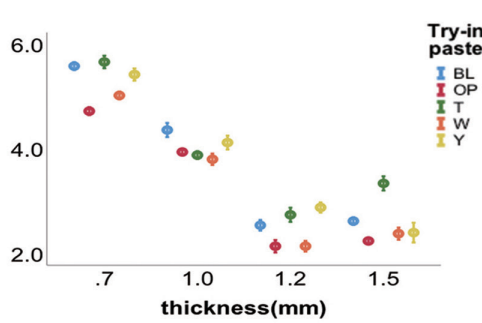

$\mathbf{F}$

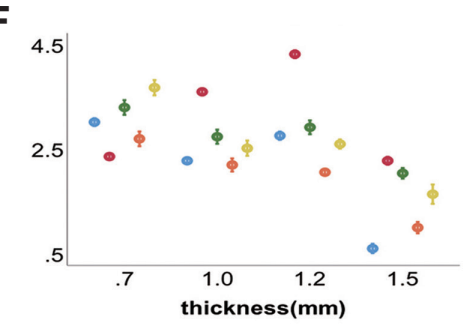

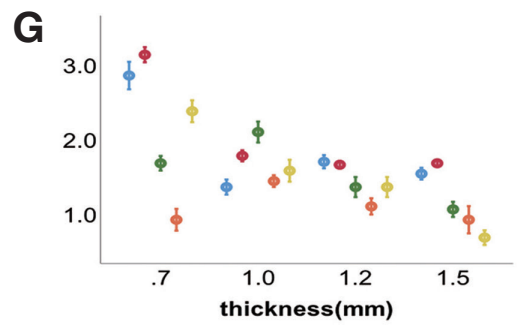

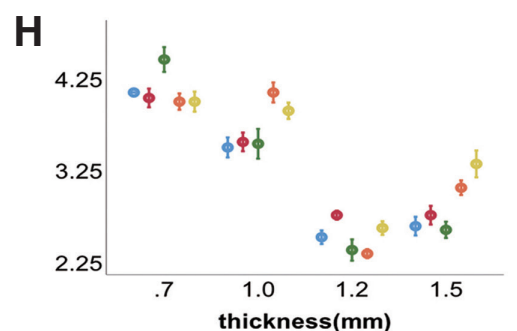

Fig. 3. Means and standard deviations of $\Delta \mathrm{E}$ values for opaque porcelain sintered $\mathrm{Co}-\mathrm{Cr}$ alloy substrate groups. Groups of zirconia in $1 M 1$ shade $(A), 1 M 2$ shade $(B), 2 M 1$ shade $(C), 2 M 2$ shade $(D), 2 M 3$ shade $(E), 3 M 2$ shade $(F)$, 4M2 shade (G) and $5 \mathrm{M} 2$ shade $(\mathrm{H})$.
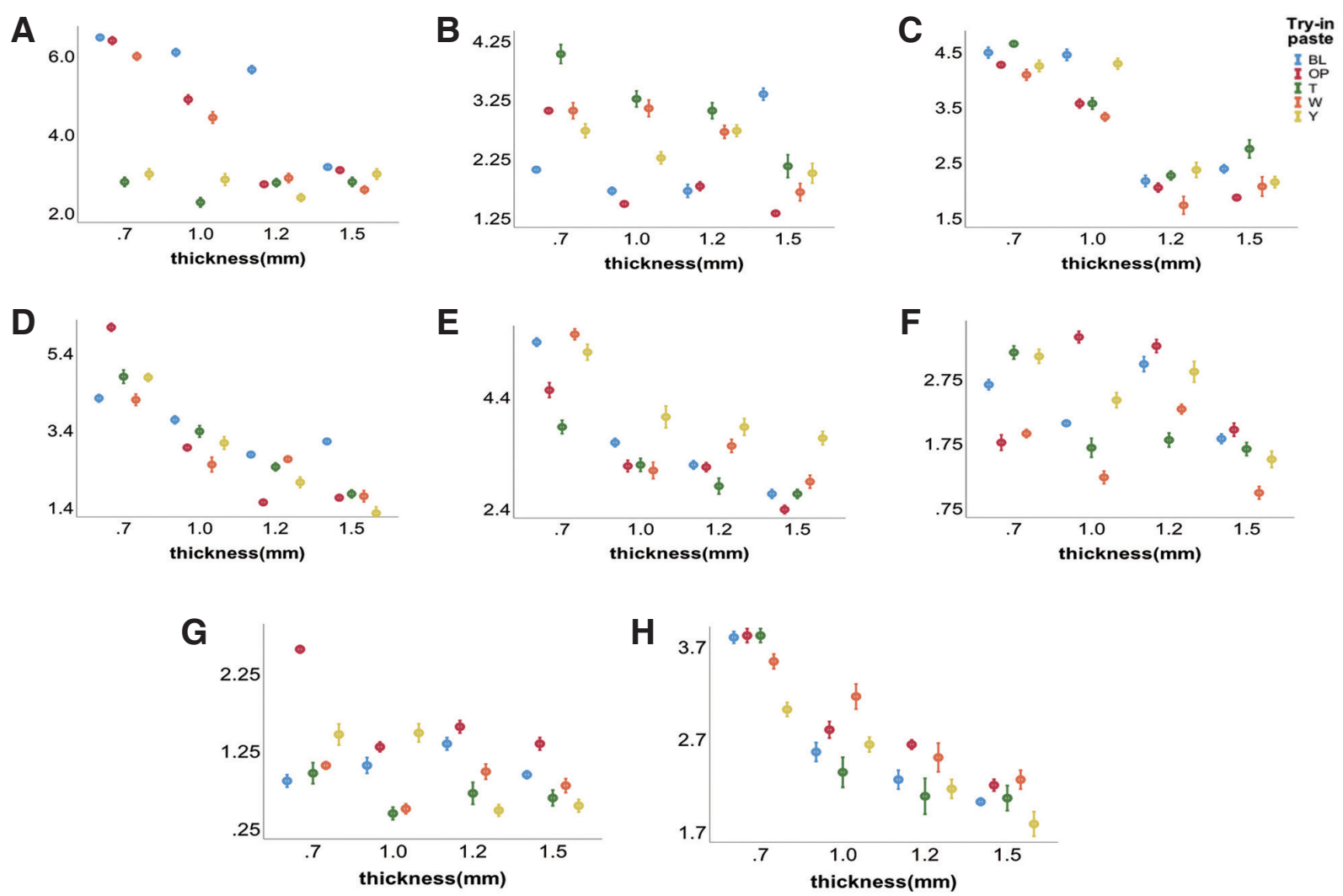

Fig. 4. Means and standard deviations of $\Delta \mathrm{E}$ values for opaque porcelain sintered precious-metal substrate groups. Groups of zirconia in $1 M 1$ shade (A), $1 M 2$ shade (B), $2 M 1$ shade (C), 2M2 shade (D), $2 M 3$ shade (E), 3M2 shade (F), $4 \mathrm{M} 2$ shade $(\mathrm{G})$ and $5 \mathrm{M} 2$ shade $(\mathrm{H})$. 
A

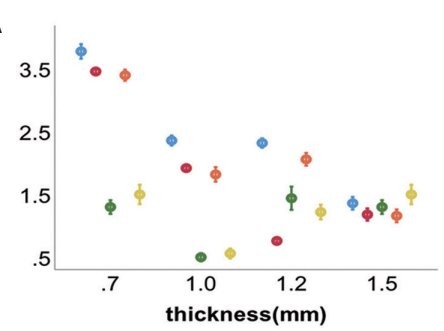

D

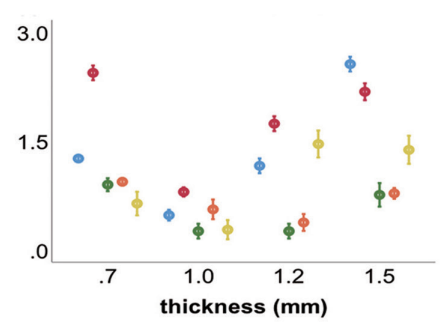

B

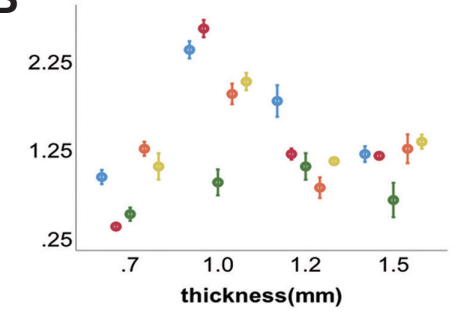

E

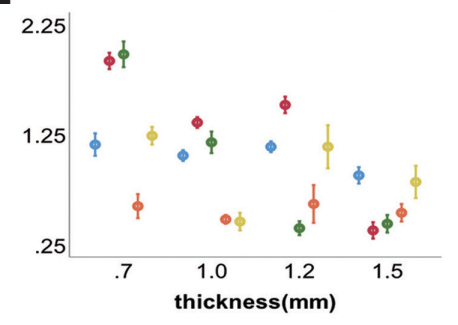

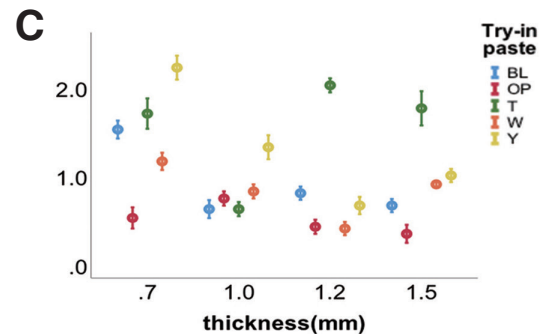

$\mathbf{F}$

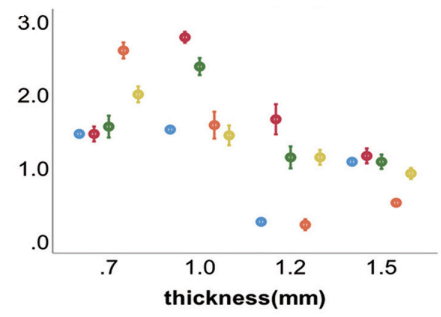

G

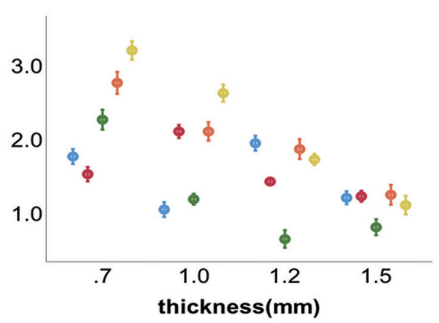

H

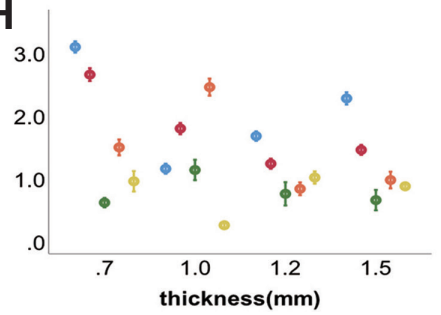

Fig. 5. Means and standard deviations of $\Delta \mathrm{E}$ values for $5 \mathrm{M} 3$ shade substrate groups. Groups of zirconia in $1 \mathrm{M} 1$ shade (A), $1 M 2$ shade $(B), 2 M 1$ shade $(C), 2 M 2$ shade $(D), 2 M 3$ shade $(E), 3 M 2$ shade $(F), 4 M 2$ shade $(G)$ and $5 M 2$ shade $(H)$.

which shade of try-in paste was chosen. When thickness was $0.7 \mathrm{~mm}, 7$ shades of zirconia (except $2 \mathrm{M} 3$ ) yielded $\Delta \mathrm{E}$ values of $<5.5$ when we used suitable shades of try-in paste. However, no shade of try-in paste brought $\Delta \mathrm{E}$ values of $0.7-\mathrm{mm} 2 \mathrm{M} 3$-shade zirconia specimens below 5.5.

In contrast to the Co-Cr alloy substrate, for the precious-metal substrate, $0.7-1.5 \mathrm{~mm}$ Lava Plus zirconia specimens in all 8 shades could yield $\Delta \mathrm{E}$ values of $<5.5$, no matter which shade of try-in paste was used. When zirconia thickness was $1.5 \mathrm{~mm}, \Delta \mathrm{E}$ values of all 8 shades of zirconia specimens on the precious-metal substrate were $<2.6$, regardless of try-in paste shade. When zirconia thickness was $1.2 \mathrm{~mm}$, using suitable shades of try-in paste yielded $\Delta \mathrm{E}$ values of $<2.6$. When zirconia thickness was $1.0 \mathrm{~mm}$, using suitable shades of try-in paste provided $\Delta \mathrm{E}$ values $<$ 2.6 for 6 shades of zirconia (except 2M1 and 3M2); when thickness was $0.7 \mathrm{~mm}$, using suitable shades of try-in paste provided $\Delta \mathrm{E}$ values of $<2.6$ for all shades of zirconia except $3 \mathrm{M} 2$ and $4 \mathrm{M} 2$.

Sintering opaque porcelain onto the precious-metal substrate did not reduce the $\Delta \mathrm{E}$ value of any of the 8 shades of Lava Plus high-translucency zirconia, unlike the results for the Co-Cr alloy substrate and contrary to our expectations. Conversely, opaque-porcelain sintering increased col- or difference in several groups. Zirconia specimens thicker than $1.0 \mathrm{~mm}$ in all shades except $1 \mathrm{M} 1$ and yielded $\Delta \mathrm{E}$ values $<5.5$, no matter which shade of try-in paste was chosen. $1.5 \mathrm{~mm}$ thick Specimens in all 8 shades could yield $\Delta \mathrm{E}$ values of $<2.6$ when suitable shades of try-in paste were used. When thickness was $1.2 \mathrm{~mm}$, zirconia specimens in all shades except $2 \mathrm{M} 3$ could yield $\Delta \mathrm{E}$ values of $<2.6$ when suitable shades of try-in paste were chosen. When thickness was $1.0 \mathrm{~mm}$, zirconia specimens in all shades except 2M1 and $2 \mathrm{M} 3$ yielded $\Delta \mathrm{E}$ values of $<2.6$ with the use of suitable try-in paste shades. When thickness was $0.7 \mathrm{~mm}$, only the $1 \mathrm{M} 2,3 \mathrm{M} 2$, and $4 \mathrm{M} 2$ shades of zirconia with suitable shades of try-in paste provided $\Delta \mathrm{E}$ values of $<2.6$.

Tables 1 - 5 provide a detailed guide for choosing try-in paste shades to achieve $\Delta \mathrm{E}$ values of $<2.6$ or $<5.5$ for Lava Plus high-translucency monolithic-zirconia restorations.

\section{DISCUSSION}

According to our results, the final colors of Lava Plus hightranslucency zirconia on different substrates deviated from target shades to different extents, affected by try-in paste shade, thickness and shade of zirconia, and discoloration of substrates. 
Table 1. Masking ability of the zirconia specimens on the $5 \mathrm{M} 3$ shade substrate

\begin{tabular}{|c|c|c|c|c|c|}
\hline & & \multicolumn{4}{|c|}{ Thickness (mm) } \\
\hline & & 0.7 & 1.0 & 1.2 & 1.5 \\
\hline \multirow{8}{*}{ Shade of zirconia } & $1 \mathrm{M} 1$ & $\mathrm{t}^{\mathrm{a}}<\mathrm{y}^{\mathrm{b}}<\mathrm{W}^{\mathrm{c}}<\mathrm{O}^{\mathrm{c}}<\mathrm{B}^{\mathrm{d}}$ & $\mathrm{t}^{\mathrm{a}}<\mathrm{y}^{\mathrm{a}}<\mathrm{w}^{\mathrm{b}}<\mathrm{O}^{\mathrm{c}}<\mathrm{b}^{\mathrm{d}}$ & $\mathrm{O}^{\mathrm{a}}<\mathrm{y}^{\mathrm{b}}<\mathrm{t}^{\mathrm{c}}<\mathrm{w}^{\mathrm{d}}<\mathrm{b}^{\mathrm{e}}$ & $\mathrm{w}^{\mathrm{a}, \mathrm{b}}<\mathrm{O}^{\mathrm{b}}<\mathrm{t}^{\mathrm{b}, \mathrm{c}}<\mathrm{b}^{\mathrm{c}}<\mathrm{y}^{\mathrm{c}}$ \\
\hline & $1 \mathrm{M} 2$ & $\mathrm{o}^{\mathrm{a}}<\mathrm{t}^{\mathrm{b}}<\mathrm{b}^{\mathrm{c}}<\mathrm{y}^{\mathrm{d}}<\mathrm{w}^{e}$ & $\mathrm{t}^{\mathrm{a}}<\mathrm{w}^{\mathrm{b}}<\mathrm{y}^{\mathrm{b}}<\mathrm{b}^{\mathrm{c}}<\mathrm{O}^{\mathrm{d}}$ & $w^{a}<t^{b}<y^{b}<0^{b}<b^{c}$ & $\mathrm{t}^{\mathrm{a}}<\mathrm{O}^{\mathrm{b}}<\mathrm{b}^{\mathrm{b}}<\mathrm{w}^{\mathrm{b}}<\mathrm{y}^{\mathrm{b}}$ \\
\hline & $2 \mathrm{M} 1$ & $\mathrm{O}^{\mathrm{a}}<\mathrm{w}^{\mathrm{b}}<\mathrm{b}^{\mathrm{c}}<\mathrm{t}^{\mathrm{c}}<\mathrm{y}^{\mathrm{d}}$ & $\mathrm{t}^{\mathrm{a}}<\mathrm{b}^{\mathrm{a}}<\mathrm{O}^{\mathrm{a}, \mathrm{b}}<\mathrm{w}^{\mathrm{b}}<\mathrm{y}^{\mathrm{c}}$ & $\mathrm{w}^{\mathrm{a}}=\mathrm{O}^{\mathrm{a}}<\mathrm{y}^{\mathrm{b}}<\mathrm{b}^{\mathrm{c}}<\mathrm{t}^{\mathrm{d}}$ & $\mathrm{O}^{\mathrm{a}}<\mathrm{b}^{\mathrm{b}}<\mathrm{w}^{\mathrm{c}}<\mathrm{y}^{\mathrm{c}}<\mathrm{t}^{\mathrm{d}}$ \\
\hline & $2 \mathrm{M} 2$ & $\mathrm{y}^{\mathrm{a}}<\mathrm{t}^{\mathrm{b}}<\mathrm{w}^{\mathrm{b}}<\mathrm{b}^{\mathrm{c}}<\mathrm{O}^{\mathrm{d}}$ & $\mathrm{t}^{\mathrm{a}}<\mathrm{y}^{\mathrm{a}}<\mathrm{b}^{\mathrm{b}}<\mathrm{w}^{\mathrm{b}}<\mathrm{O}^{\mathrm{c}}$ & $\mathrm{t}^{\mathrm{a}}<\mathrm{w}^{\mathrm{a}}<\mathrm{b}^{\mathrm{b}}<\mathrm{y}^{\mathrm{c}}<\mathrm{O}^{\mathrm{d}}$ & $\mathrm{t}^{\mathrm{a}}<\mathrm{W}^{\mathrm{a}}<\mathrm{y}^{\mathrm{b}}<\mathrm{O}^{\mathrm{c}}<\mathrm{b}^{\mathrm{d}}$ \\
\hline & $2 \mathrm{M3}$ & $\mathrm{w}^{\mathrm{a}}<\mathrm{b}^{\mathrm{b}}<\mathrm{y}^{\mathrm{b}}<\mathrm{O}^{\mathrm{c}}<\mathrm{t}^{\mathrm{c}}$ & $\mathrm{y}^{\mathrm{a}}<\mathrm{w}^{\mathrm{a}}<\mathrm{b}^{\mathrm{b}}<\mathrm{t}^{\mathrm{c}}<\mathrm{O}^{\mathrm{d}}$ & $\mathrm{t}^{\mathrm{a}}<\mathrm{w}^{\mathrm{b}}<\mathrm{b}^{\mathrm{c}}<\mathrm{y}^{\mathrm{c}}<\mathrm{O}^{\mathrm{d}}$ & $\mathrm{O}^{\mathrm{a}}<\mathrm{t}^{\mathrm{b}}<\mathrm{w}^{\mathrm{b}}<\mathrm{y}^{\mathrm{c}}<\mathrm{b}^{\mathrm{c}}$ \\
\hline & 3M2 & $\mathrm{O}^{\mathrm{a}}<\mathrm{b}^{\mathrm{a}}<\mathrm{t}^{\mathrm{a}}<\mathrm{y}^{\mathrm{b}}<\mathrm{w}^{\mathrm{c}}$ & $\mathrm{y}^{\mathrm{a}}<\mathrm{b}^{\mathrm{a}}<\mathrm{w}^{\mathrm{a}}<\mathrm{t}^{\mathrm{b}}<\mathrm{O}^{\mathrm{c}}$ & $\mathrm{w}^{\mathrm{a}}<\mathrm{b}^{\mathrm{a}}<\mathrm{y}^{\mathrm{b}}<\mathrm{t}^{\mathrm{b}}<\mathrm{O}^{\mathrm{c}}$ & $\mathrm{w}^{\mathrm{a}}<\mathrm{y}^{\mathrm{a}}<\mathrm{b}^{\mathrm{b}}<\mathrm{t}^{\mathrm{b}}<\mathrm{O}^{\mathrm{b}}$ \\
\hline & $4 \mathrm{M} 2$ & $\mathrm{O}^{\mathrm{a}}<\mathrm{b}^{\mathrm{a}}<\mathrm{t}^{\mathrm{a}}<\mathrm{W}^{\mathrm{b}}<\mathrm{Y}^{\mathrm{c}}$ & $\mathrm{b}^{\mathrm{a}}<\mathrm{t}^{\mathrm{b}}<\mathrm{W}^{\mathrm{c}}<\mathrm{O}^{\mathrm{c}}<\mathrm{Y}^{\mathrm{d}}$ & $\mathrm{t}^{\mathrm{a}}<\mathrm{O}^{\mathrm{b}}<\mathrm{y}^{\mathrm{c}}<\mathrm{w}^{\mathrm{c}}<\mathrm{b}^{\mathrm{c}}$ & $\mathrm{t}^{\mathrm{a}}<\mathrm{y}^{\mathrm{b}}<\mathrm{b}^{\mathrm{b}}<\mathrm{O}^{\mathrm{b}}<\mathrm{w}^{\mathrm{b}}$ \\
\hline & $5 \mathrm{M} 2$ & $\mathrm{t}^{\mathrm{a}}<\mathrm{y}^{\mathrm{b}}<\mathrm{w}^{\mathrm{c}}<\mathrm{O}^{\mathrm{d}}<\mathrm{B}^{\mathrm{e}}$ & $\mathrm{y}^{\mathrm{a}}<\mathrm{t}^{\mathrm{b}}<\mathrm{b}^{\mathrm{b}}<\mathrm{O}^{\mathrm{c}}<\mathrm{w}^{\mathrm{c}}$ & $\mathrm{t}^{\mathrm{a}}<\mathrm{w}^{\mathrm{b}}<\mathrm{y}^{\mathrm{b}}<\mathrm{O}^{\mathrm{c}}<\mathrm{b}^{\mathrm{d}}$ & $\mathrm{t}^{\mathrm{a}}<\mathrm{y}^{\mathrm{b}}<\mathrm{w}^{\mathrm{b}}<\mathrm{O}^{\mathrm{c}}<\mathrm{b}^{\mathrm{d}}$ \\
\hline
\end{tabular}

* $W(w), Y(y), T(t), B(b)$ and $O(o)$, respectively, represent the $\Delta E$ values of different groups using try-in pastes in shades of white, yellow, transparent, bleach and opaque; Capital letters $(\mathrm{W}, \mathrm{Y}, \mathrm{T}, \mathrm{B}, \mathrm{O})$ mean $2.6 \leq \Delta \mathrm{E}<5.5$; Lowercases ( $\mathrm{W}, \mathrm{y}, \mathrm{t}, \mathrm{b}, \mathrm{o})$ mean $\Delta \mathrm{E}<2.6$; Same superscripts represent no statistical difference between the groups.

Table 2. Masking ability of the zirconia specimens on the Co-Cr alloy substrates

\begin{tabular}{|c|c|c|c|c|c|}
\hline & & \multicolumn{4}{|c|}{ Thickness (mm) } \\
\hline & & 0.7 & 1.0 & 1.2 & 1.5 \\
\hline \multirow{8}{*}{ Shade of zirconia } & $1 \mathrm{M} 1$ & & $\mathrm{O}^{\mathrm{a}}<\mathrm{B}^{\mathrm{a}}$ & $B$ & $\mathrm{O}^{\mathrm{a}}<\mathrm{B}^{\mathrm{a}}$ \\
\hline & $1 \mathrm{M} 2$ & & & & \\
\hline & $2 \mathrm{M} 1$ & Y & $Y^{a}<T^{b}<W^{c}$ & $\mathrm{~T}^{\mathrm{a}}<\mathrm{Y}^{\mathrm{b}}<\mathrm{O}^{\mathrm{b}}$ & $\mathrm{T}^{\mathrm{a}}<\mathrm{O}^{\mathrm{b}}<\mathrm{B}^{\mathrm{c}}<\mathrm{Y}^{\mathrm{d}}<\mathrm{W}^{\mathrm{d}}$ \\
\hline & $2 \mathrm{M} 2$ & & & & \\
\hline & $2 \mathrm{M} 3$ & & & $W^{a}<O^{b}<Y^{b}<B^{c}$ & $\mathrm{~B}^{\mathrm{a}}<\mathrm{O}^{\mathrm{b}}<\mathrm{T}^{\mathrm{b}}<\mathrm{Y}^{\mathrm{b}}<\mathrm{W}^{\mathrm{c}}$ \\
\hline & $3 \mathrm{M} 2$ & & & & $\mathrm{O}^{\mathrm{a}}<\mathrm{B}^{\mathrm{b}}<\mathrm{T}^{\mathrm{c}}<\mathrm{Y}^{\mathrm{d}}<\mathrm{W}^{\mathrm{e}}$ \\
\hline & $4 \mathrm{M} 2$ & & & & $\mathrm{~W}^{\mathrm{a}}<\mathrm{O}^{\mathrm{a}}<\mathrm{Y}^{\mathrm{b}}<\mathrm{B}^{\mathrm{b}, \mathrm{c}}<\mathrm{T}^{\mathrm{c}}$ \\
\hline & $5 \mathrm{M} 2$ & $\mathrm{O}$ & & $\mathrm{O}^{\mathrm{a}}<\mathrm{Y}^{\mathrm{b}}<\mathrm{T}^{\mathrm{b}}<\mathrm{B}^{\mathrm{b}}<\mathrm{W}^{\mathrm{c}}$ & $\mathrm{O}^{\mathrm{a}}<\mathrm{B}^{\mathrm{a}, \mathrm{b}}<\mathrm{Y}^{\mathrm{b}}<\mathrm{T}^{\mathrm{c}}<\mathrm{W}^{\mathrm{d}}$ \\
\hline
\end{tabular}

* $W(w), Y(y), T(t), B(b)$ and $O(o)$, respectively, represent the $\Delta E$ values of different groups using try-in pastes in shades of white, yellow, transparent, bleach and opaque; Capital letters (W, Y, T, B, O) mean $2.6 \leq \Delta \mathrm{E}<5.5$; Lowercases ( $\mathrm{W}, \mathrm{y}, \mathrm{t}, \mathrm{b}, \mathrm{o})$ mean $\Delta \mathrm{E}<2.6$; Same superscripts represent no statistical difference between the groups.

Table 3. Masking ability of the zirconia specimens on the precious-metal substrate

\begin{tabular}{|c|c|c|c|c|c|}
\hline & & \multicolumn{4}{|c|}{ Thickness (mm) } \\
\hline & & 0.7 & 1.0 & 1.2 & 1.5 \\
\hline \multirow{8}{*}{ Shade of zirconia } & $1 \mathrm{M} 1$ & $\mathrm{t}^{\mathrm{a}}<\mathrm{y}^{\mathrm{b}}<\mathrm{O}^{\mathrm{c}}<\mathrm{B}^{\mathrm{d}}<\mathrm{W}^{\mathrm{d}}$ & $\mathrm{y}^{\mathrm{a}}<\mathrm{O}^{\mathrm{b}}<\mathrm{t}^{\mathrm{c}}<\mathrm{b}^{\mathrm{d}}<\mathrm{w}^{\mathrm{e}}$ & $\mathrm{O}^{\mathrm{a}}<\mathrm{t}^{\mathrm{b}}<\mathrm{B}^{\mathrm{b}}<\mathrm{Y}^{\mathrm{b}}<\mathrm{W}^{\mathrm{c}}$ & $\mathrm{O}^{\mathrm{a}}<\mathrm{t}^{\mathrm{b}}<\mathrm{b}^{\mathrm{b}}<\mathrm{y}^{\mathrm{c}}<\mathrm{w}^{\mathrm{d}}$ \\
\hline & $1 \mathrm{M} 2$ & $\mathrm{O}^{\mathrm{a}}<\mathrm{y}^{\mathrm{b}}<\mathrm{t}^{\mathrm{c}}<\mathrm{B}^{\mathrm{c}}<\mathrm{W}^{\mathrm{d}}$ & $\mathrm{y}^{\mathrm{a}}<\mathrm{T}^{\mathrm{b}}<\mathrm{W}^{\mathrm{c}}<\mathrm{B}^{\mathrm{d}}<\mathrm{O}^{\mathrm{e}}$ & $\mathrm{b}^{\mathrm{a}}<\mathrm{w}^{\mathrm{b}}<\mathrm{y}^{\mathrm{b}}<\mathrm{T}^{\mathrm{c}}<\mathrm{O}^{\mathrm{d}}$ & $\mathrm{t}^{\mathrm{a}}<\mathrm{y}^{\mathrm{b}}<\mathrm{w}^{\mathrm{c}}<\mathrm{O}^{\mathrm{d}}<\mathrm{b}^{\mathrm{e}}$ \\
\hline & $2 \mathrm{M} 1$ & $\mathrm{~W}^{\mathrm{a}}<\mathrm{O}^{\mathrm{a}}<\mathrm{Y}^{\mathrm{b}}<\mathrm{B}^{\mathrm{c}}<\mathrm{T}^{\mathrm{c}}$ & $\mathrm{O}^{\mathrm{a}}<\mathrm{W}^{\mathrm{b}}=\mathrm{T}^{\mathrm{b}}<\mathrm{Y}^{\mathrm{c}}<\mathrm{B}^{\mathrm{c}}$ & $\mathrm{y}^{\mathrm{a}}<\mathrm{b}^{\mathrm{b}}<\mathrm{O}^{\mathrm{c}}<\mathrm{w}^{\mathrm{d}}<\mathrm{t}^{\mathrm{d}}$ & $\mathrm{w}^{\mathrm{a}}<\mathrm{b}^{\mathrm{b}}<\mathrm{O}^{\mathrm{b}}<\mathrm{y}^{\mathrm{c}}<\mathrm{t}^{\mathrm{d}}$ \\
\hline & $2 \mathrm{M} 2$ & $\mathrm{~b}^{\mathrm{a}}<\mathrm{O}^{\mathrm{b}}<\mathrm{W}^{\mathrm{b}, \mathrm{c}}<\mathrm{Y}^{\mathrm{c}}<\mathrm{T}^{\mathrm{d}}$ & $\mathrm{y}^{\mathrm{a}}<\mathrm{t}^{\mathrm{b}}<\mathrm{b}^{\mathrm{b}}=\mathrm{O}^{\mathrm{b}}<\mathrm{w}^{\mathrm{c}}$ & $\mathrm{y}^{\mathrm{a}}<\mathrm{t}^{\mathrm{b}}<\mathrm{b}^{\mathrm{c}}<\mathrm{w}^{\mathrm{d}}<\mathrm{O}^{\mathrm{d}}$ & $\mathrm{y}^{\mathrm{a}}<\mathrm{t}^{\mathrm{b}}<\mathrm{b}^{\mathrm{c}}<\mathrm{w}^{\mathrm{d}}<\mathrm{O}^{\mathrm{e}}$ \\
\hline & $2 \mathrm{M} 3$ & $\mathrm{O}^{\mathrm{a}}<\mathrm{b}^{\mathrm{a}}<\mathrm{W}^{\mathrm{c}}<\mathrm{Y}^{\mathrm{d}}<\mathrm{T}^{\mathrm{d}}$ & $\mathrm{t}^{\mathrm{a}}<\mathrm{w}^{\mathrm{a}}<\mathrm{y}^{\mathrm{b}}<\mathrm{b}^{\mathrm{c}}<\mathrm{O}^{\mathrm{d}}$ & $\mathrm{t}^{\mathrm{a}}<\mathrm{b}^{\mathrm{b}}<\mathrm{w}^{\mathrm{c}}<\mathrm{O}^{\mathrm{c}}<\mathrm{y}^{\mathrm{d}}$ & $\mathrm{b}^{\mathrm{a}}<\mathrm{y}^{\mathrm{b}}<\mathrm{t}^{\mathrm{b}}<\mathrm{O}^{\mathrm{c}}<\mathrm{w}^{\mathrm{d}}$ \\
\hline & $3 \mathrm{M} 2$ & $\mathrm{~B}^{\mathrm{a}}<\mathrm{T}^{\mathrm{b}}<\mathrm{O}^{\mathrm{b}, \mathrm{c}}<\mathrm{W}^{\mathrm{c}}<\mathrm{Y}^{\mathrm{d}}$ & $\mathrm{T}^{\mathrm{a}}<\mathrm{W}^{\mathrm{b}}<\mathrm{B}^{\mathrm{b}}<\mathrm{Y}^{\mathrm{c}}<\mathrm{O}^{\mathrm{c}}$ & $\mathrm{b}^{\mathrm{a}}<\mathrm{y}^{\mathrm{a}, \mathrm{b}}<\mathrm{t}^{\mathrm{b}}<\mathrm{W}^{\mathrm{c}}<\mathrm{O}^{\mathrm{c}}$ & $\mathrm{b}^{\mathrm{a}}<\mathrm{O}^{\mathrm{b}}<\mathrm{t}^{\mathrm{b}}<\mathrm{y}^{\mathrm{c}}<\mathrm{w}^{\mathrm{d}}$ \\
\hline & $4 \mathrm{M} 2$ & $\mathrm{O}^{\mathrm{a}}<\mathrm{B}^{\mathrm{b}}<\mathrm{W}^{\mathrm{c}}<\mathrm{Y}^{\mathrm{c}}<\mathrm{T}^{\mathrm{d}}$ & $\mathrm{t}^{\mathrm{a}}<\mathrm{w}^{\mathrm{b}}<\mathrm{y}^{\mathrm{b}}<\mathrm{B}^{\mathrm{c}}<\mathrm{O}^{\mathrm{d}}$ & $\mathrm{b}^{\mathrm{a}}<\mathrm{t}^{\mathrm{b}}<\mathrm{y}^{\mathrm{b}}<\mathrm{w}^{\mathrm{b}}<\mathrm{O}^{\mathrm{c}}$ & $\mathrm{y}^{\mathrm{a}}<\mathrm{w}^{\mathrm{a}}<\mathrm{t}^{\mathrm{b}}<\mathrm{O}^{\mathrm{c}}<\mathrm{b}^{\mathrm{c}}$ \\
\hline & $5 \mathrm{M} 2$ & $\mathrm{~b}^{\mathrm{a}}<\mathrm{y}^{\mathrm{b}}<\mathrm{t}^{\mathrm{c}}<\mathrm{w}^{\mathrm{c}}<\mathrm{O}^{\mathrm{d}}$ & $\mathrm{t}^{\mathrm{a}}<\mathrm{y}^{\mathrm{a}}<\mathrm{w}^{\mathrm{b}}<\mathrm{b}^{\mathrm{c}}<\mathrm{O}^{\mathrm{d}}$ & $\mathrm{t}^{\mathrm{a}}<\mathrm{w}^{\mathrm{a}}<\mathrm{y}^{\mathrm{a}}<\mathrm{O}^{\mathrm{b}}<\mathrm{b}^{\mathrm{c}}$ & $\mathrm{t}^{\mathrm{a}}<\mathrm{b}^{\mathrm{b}}<\mathrm{y}^{\mathrm{b}}<\mathrm{w}^{\mathrm{c}}<\mathrm{O}^{\mathrm{d}}$ \\
\hline
\end{tabular}

${ }^{*} W(w), Y(y), T(t), B(b)$ and $O(o)$, respectively, represent the $\Delta E$ values of different groups using try-in pastes in shades of white, yellow, transparent, bleach and opaque; Capital letters $(\mathrm{W}, \mathrm{Y}, \mathrm{T}, \mathrm{B}, \mathrm{O})$ mean $2.6 \leq \Delta \mathrm{E}<5.5$; Lowercases ( $\mathrm{w}, \mathrm{y}, \mathrm{t}, \mathrm{b}, \mathrm{o})$ mean $\Delta \mathrm{E}<2.6$; Same superscripts represent no statistical difference between the groups. 
Table 4. Masking ability of the zirconia specimens on the opaque porcelain sintered Co-Cr alloy substrate

\begin{tabular}{|c|c|c|c|c|c|}
\hline & & \multicolumn{4}{|c|}{ Thickness (mm) } \\
\hline & & 0.7 & 1.0 & 1.2 & 1.5 \\
\hline \multirow{8}{*}{ Shade of zirconia } & $1 \mathrm{M} 1$ & $\mathrm{~T}^{\mathrm{a}}<\mathrm{Y}^{\mathrm{b}}$ & $\mathrm{T}^{\mathrm{a}}<\mathrm{Y}^{\mathrm{b}}<\mathrm{W}^{\mathrm{c}}$ & $\mathrm{Y}^{\mathrm{a}}<\mathrm{W}^{\mathrm{b}}<\mathrm{T}^{\mathrm{c}}<\mathrm{O}^{\mathrm{c}}<\mathrm{B}^{\mathrm{d}}$ & $\mathrm{W}^{\mathrm{a}}=\mathrm{B}^{\mathrm{a}}<\mathrm{T}^{\mathrm{a}}<\mathrm{O}^{\mathrm{b}}<\mathrm{Y}^{\mathrm{c}}$ \\
\hline & $1 \mathrm{M} 2$ & $\mathrm{~B}^{\mathrm{a}}<\mathrm{W}^{\mathrm{a}}<\mathrm{Y}^{\mathrm{b}}<\mathrm{O}^{\mathrm{c}}<\mathrm{T}^{\mathrm{d}}$ & $\mathrm{O}^{\mathrm{a}}<\mathrm{b}^{\mathrm{b}}<\mathrm{W}^{\mathrm{c}}<\mathrm{Y}^{\mathrm{d}}<\mathrm{T}^{\mathrm{e}}$ & $\mathrm{b}^{\mathrm{a}}<\mathrm{O}^{\mathrm{b}}<\mathrm{W}^{\mathrm{c}}<\mathrm{Y}^{\mathrm{d}}<\mathrm{T}^{\mathrm{e}}$ & $\mathrm{O}^{\mathrm{a}}<\mathrm{w}^{\mathrm{b}}<\mathrm{y}^{\mathrm{c}}<\mathrm{T}^{\mathrm{c}}<\mathrm{B}^{\mathrm{d}}$ \\
\hline & $2 \mathrm{M} 1$ & $\mathrm{O}^{\mathrm{a}}<\mathrm{W}^{\mathrm{b}}<\mathrm{Y}^{\mathrm{c}}$ & $\mathrm{W}^{\mathrm{a}}<\mathrm{T}^{\mathrm{a}}<\mathrm{O}^{\mathrm{a}}<\mathrm{Y}^{\mathrm{b}}<\mathrm{B}^{\mathrm{c}}$ & $W^{a}=0^{a}<b^{b}<Y^{c}<T^{c}$ & $\mathrm{O}^{\mathrm{a}}<\mathrm{W}^{\mathrm{a}}=\mathrm{y}^{\mathrm{a}}<\mathrm{B}^{\mathrm{b}}<\mathrm{T}^{\mathrm{c}}$ \\
\hline & $2 \mathrm{M} 2$ & $\mathrm{~B}^{\mathrm{a}}<\mathrm{T}^{\mathrm{a}}$ & $\mathrm{O}^{\mathrm{a}}<\mathrm{Y}^{\mathrm{b}}<\mathrm{W}^{\mathrm{c}}<\mathrm{T}^{\mathrm{c}, \mathrm{d}}<\mathrm{B}^{\mathrm{d}}$ & $\mathrm{O}^{\mathrm{a}}<\mathrm{W}^{\mathrm{b}}<\mathrm{T}^{\mathrm{c}}<\mathrm{Y}^{\mathrm{d}}<\mathrm{B}^{\mathrm{e}}$ & $\mathrm{O}^{\mathrm{a}}<\mathrm{y}^{\mathrm{b}}<\mathrm{w}^{\mathrm{c}}<\mathrm{t}^{\mathrm{d}}<\mathrm{B}^{\mathrm{e}}$ \\
\hline & $2 \mathrm{M} 3$ & & $\mathrm{O}^{\mathrm{a}}<\mathrm{B}^{\mathrm{b}}<\mathrm{T}^{\mathrm{c}}<\mathrm{W}^{\mathrm{c}}<\mathrm{Y}^{\mathrm{d}}$ & $\mathrm{B}^{\mathrm{a}}<\mathrm{W}^{\mathrm{a}}<\mathrm{T}^{\mathrm{b}}<\mathrm{O}^{\mathrm{b}}<\mathrm{Y}^{\mathrm{c}}$ & $\mathrm{O}^{\mathrm{a}}<\mathrm{B}^{\mathrm{b}}<\mathrm{W}^{\mathrm{c}}<\mathrm{T}^{\mathrm{c}}<\mathrm{Y}^{\mathrm{c}}$ \\
\hline & $3 \mathrm{M} 2$ & $\mathrm{O}^{\mathrm{a}}<\mathrm{W}^{\mathrm{b}}<\mathrm{B}^{\mathrm{c}}<\mathrm{T}^{\mathrm{d}}<\mathrm{Y}^{\mathrm{e}}$ & $\mathrm{w}^{\mathrm{a}}<\mathrm{b}^{\mathrm{a}}<\mathrm{y}^{\mathrm{b}}<\mathrm{T}^{\mathrm{c}}<\mathrm{O}^{\mathrm{d}}$ & $\mathrm{W}^{\mathrm{a}}<\mathrm{Y}^{\mathrm{b}}<\mathrm{B}^{\mathrm{c}}<\mathrm{T}^{\mathrm{d}}<\mathrm{O}^{\mathrm{e}}$ & $\mathrm{b}^{\mathrm{a}}<\mathrm{w}^{\mathrm{b}}<\mathrm{y}^{\mathrm{c}}<\mathrm{t}^{\mathrm{d}}<\mathrm{O}^{\mathrm{e}}$ \\
\hline & $4 \mathrm{M} 2$ & $\mathrm{w}^{\mathrm{a}}<\mathrm{t}^{\mathrm{b}}<\mathrm{y}^{\mathrm{c}}<\mathrm{B}^{\mathrm{d}}<\mathrm{O}^{\mathrm{e}}$ & $\mathrm{b}^{\mathrm{a}}<\mathrm{w}^{\mathrm{a}, \mathrm{b}}<\mathrm{y}^{\mathrm{b}}<\mathrm{O}^{\mathrm{c}}<\mathrm{t}^{\mathrm{d}}$ & $\mathrm{w}^{\mathrm{a}}<\mathrm{t}^{\mathrm{b}}<\mathrm{y}^{\mathrm{b}}<\mathrm{O}^{\mathrm{c}}<\mathrm{b}^{\mathrm{c}}$ & $\mathrm{y}^{\mathrm{a}}<\mathrm{w}^{\mathrm{b}}<\mathrm{t}^{\mathrm{c}}<\mathrm{b}^{\mathrm{d}}<\mathrm{O}^{\mathrm{e}}$ \\
\hline & $5 \mathrm{M} 2$ & $W^{a}=Y^{a}<O^{a}<B^{a}<T^{b}$ & $\mathrm{~B}^{\mathrm{a}}<\mathrm{T}^{\mathrm{a}}<\mathrm{O}^{\mathrm{a}}<\mathrm{Y}^{\mathrm{b}}<\mathrm{W}^{\mathrm{b}}$ & $\mathrm{w}^{\mathrm{a}}<\mathrm{t}^{\mathrm{a}}<\mathrm{b}^{\mathrm{b}}<\mathrm{Y}^{\mathrm{b}}<\mathrm{O}^{\mathrm{c}}$ & $\mathrm{t}^{\mathrm{a}}<\mathrm{B}^{\mathrm{a}}<\mathrm{O}^{\mathrm{a}}<\mathrm{W}^{\mathrm{b}}<\mathrm{Y}^{\mathrm{c}}$ \\
\hline
\end{tabular}

${ }^{*} \mathrm{~W}(\mathrm{w}), \mathrm{Y}(\mathrm{y}), \mathrm{T}(\mathrm{t}), \mathrm{B}(\mathrm{b})$ and $\mathrm{O}(\mathrm{o})$, respectively, represent the $\Delta \mathrm{E}$ values of different groups using try-in pastes in shades of white, yellow, transparent, bleach and opaque; Capital letters ( $,, Y, T, B, O)$ mean $2.6 \leq \Delta \mathrm{E}<5.5$; Lowercases ( $\mathrm{W}, \mathrm{y}, \mathrm{t}, \mathrm{b}, \mathrm{o})$ mean $\Delta \mathrm{E}<2.6$; Same superscripts represent no statistical difference between the groups.

Table 5. Masking ability of the zirconia specimens on the opaque porcelain sintered precious-metal substrate

\begin{tabular}{|c|c|c|c|c|c|}
\hline & & \multicolumn{4}{|c|}{ Thickness (mm) } \\
\hline & & 0.7 & 1.0 & 1.2 & 1.5 \\
\hline \multirow{8}{*}{ Shade of zirconia } & $1 \mathrm{M} 1$ & $\mathrm{~T}^{\mathrm{a}}<\mathrm{Y}^{\mathrm{b}}$ & $\mathrm{t}^{\mathrm{a}}<\mathrm{Y}^{\mathrm{b}}<\mathrm{W}^{\mathrm{c}}<\mathrm{O}^{\mathrm{d}}$ & $\mathrm{y}^{\mathrm{a}}<\mathrm{O}^{\mathrm{a}}<\mathrm{T}^{\mathrm{b}}<\mathrm{W}^{\mathrm{b}}$ & $\mathrm{W}^{\mathrm{a}}<\mathrm{T}^{\mathrm{b}}<\mathrm{Y}^{\mathrm{c}}<\mathrm{O}^{\mathrm{c}, \mathrm{d}}<\mathrm{B}^{\mathrm{d}}$ \\
\hline & $1 \mathrm{M} 2$ & $\mathrm{~b}^{\mathrm{a}}<\mathrm{Y}^{\mathrm{b}}<\mathrm{W}^{\mathrm{c}}<\mathrm{O}^{\mathrm{c}}<\mathrm{T}^{\mathrm{d}}$ & $\mathrm{O}^{\mathrm{a}}<\mathrm{b}^{\mathrm{b}}<\mathrm{y}^{\mathrm{c}}<\mathrm{W}^{\mathrm{d}}<\mathrm{T}^{\mathrm{e}}$ & $\mathrm{b}^{\mathrm{a}}<\mathrm{O}^{\mathrm{a}}<\mathrm{W}^{\mathrm{b}}<\mathrm{Y}^{\mathrm{b}}<\mathrm{T}^{\mathrm{c}}$ & $\mathrm{O}^{\mathrm{a}}<\mathrm{w}^{\mathrm{b}}<\mathrm{y}^{\mathrm{c}}<\mathrm{t}^{\mathrm{c}}<\mathrm{B}^{\mathrm{d}}$ \\
\hline & $2 \mathrm{M} 1$ & $\mathrm{~W}^{\mathrm{a}}<\mathrm{Y}^{\mathrm{b}}<\mathrm{O}^{\mathrm{b}}<\mathrm{B}^{\mathrm{c}}<\mathrm{T}^{\mathrm{d}}$ & $\mathrm{W}^{\mathrm{a}}<\mathrm{T}^{\mathrm{b}}<\mathrm{O}^{\mathrm{b}}<\mathrm{Y}^{\mathrm{c}}<\mathrm{B}^{\mathrm{d}}$ & $\mathrm{w}^{\mathrm{a}}<\mathrm{O}^{\mathrm{b}}<\mathrm{b}^{\mathrm{b}, \mathrm{c}}<\mathrm{t}^{\mathrm{c}, \mathrm{d}}<\mathrm{y}^{\mathrm{d}}$ & $\mathrm{O}^{\mathrm{a}}<\mathrm{w}^{\mathrm{b}}<\mathrm{y}^{\mathrm{c}}<\mathrm{b}^{\mathrm{d}}<\mathrm{T}^{\mathrm{e}}$ \\
\hline & $2 \mathrm{M} 2$ & $\mathrm{~W}^{\mathrm{a}}<\mathrm{B}^{\mathrm{a}}<\mathrm{Y}^{\mathrm{b}}<\mathrm{T}^{\mathrm{b}}$ & $\mathrm{w}^{\mathrm{a}}<\mathrm{O}^{\mathrm{b}}<\mathrm{Y}^{\mathrm{b}}<\mathrm{T}^{\mathrm{c}}<\mathrm{B}^{\mathrm{c}}$ & $\mathrm{O}^{\mathrm{a}}<\mathrm{y}^{\mathrm{b}}<\mathrm{t}^{\mathrm{c}}<\mathrm{W}^{\mathrm{d}}<\mathrm{B}^{\mathrm{d}}$ & $\mathrm{y}^{\mathrm{a}}<\mathrm{O}^{\mathrm{b}}<\mathrm{w}^{\mathrm{b}}<\mathrm{t}^{\mathrm{b}}<\mathrm{B}^{\mathrm{c}}$ \\
\hline & $2 \mathrm{M} 3$ & $\mathrm{~T}^{\mathrm{a}}<\mathrm{O}^{\mathrm{b}}<\mathrm{Y}^{\mathrm{c}}<\mathrm{B}^{\mathrm{d}}$ & $\mathrm{W}^{\mathrm{a}}<\mathrm{O}^{\mathrm{a}}<\mathrm{T}^{\mathrm{a}}<\mathrm{B}^{\mathrm{b}}<\mathrm{Y}^{\mathrm{c}}$ & $\mathrm{T}^{\mathrm{a}}<\mathrm{O}^{\mathrm{b}}<\mathrm{B}^{\mathrm{b}}<\mathrm{W}^{\mathrm{c}}<\mathrm{Y}^{\mathrm{d}}$ & $\mathrm{O}^{\mathrm{a}}<\mathrm{T}^{\mathrm{b}}<\mathrm{B}^{\mathrm{b}}<\mathrm{W}^{\mathrm{c}}<\mathrm{Y}^{\mathrm{d}}$ \\
\hline & $3 \mathrm{M} 2$ & $\mathrm{O}^{\mathrm{a}}<\mathrm{W}^{\mathrm{a}}<\mathrm{B}^{\mathrm{b}}<\mathrm{Y}^{\mathrm{c}}<\mathrm{T}^{\mathrm{c}}$ & $\mathrm{W}^{\mathrm{a}}<\mathrm{T}^{\mathrm{b}}<\mathrm{B}^{\mathrm{c}}<\mathrm{Y}^{\mathrm{d}}<\mathrm{O}^{\mathrm{e}}$ & $\mathrm{T}^{\mathrm{a}}<\mathrm{W}^{\mathrm{b}}<\mathrm{Y}^{\mathrm{c}}<\mathrm{B}^{\mathrm{c}}<\mathrm{O}^{\mathrm{d}}$ & $\mathrm{w}^{\mathrm{a}}<\mathrm{y}^{\mathrm{b}}<\mathrm{t}^{\mathrm{c}}<\mathrm{b}^{\mathrm{d}}<\mathrm{O}^{\mathrm{d}}$ \\
\hline & $4 \mathrm{M} 2$ & $\mathrm{~b}^{\mathrm{a}}<\mathrm{t}^{\mathrm{a}, \mathrm{b}}<\mathrm{w}^{\mathrm{b}}<\mathrm{y}^{\mathrm{c}}<\mathrm{O}^{\mathrm{d}}$ & $\mathrm{t}^{\mathrm{a}}<\mathrm{w}^{\mathrm{a}}<\mathrm{b}^{\mathrm{c}}<\mathrm{O}^{\mathrm{d}}<\mathrm{y}^{\mathrm{e}}$ & $\mathrm{y}^{\mathrm{a}}<\mathrm{t}^{\mathrm{b}}<\mathrm{w}^{\mathrm{c}}<\mathrm{b}^{\mathrm{d}}<\mathrm{O}^{\mathrm{e}}$ & $\mathrm{y}^{\mathrm{a}}<\mathrm{t}^{\mathrm{a}}<\mathrm{w}^{\mathrm{b}}<\mathrm{b}^{\mathrm{c}}<\mathrm{O}^{\mathrm{d}}$ \\
\hline & $5 \mathrm{M} 2$ & $\mathrm{Y}^{\mathrm{a}}<\mathrm{W}^{\mathrm{b}}<\mathrm{B}^{\mathrm{c}}<\mathrm{T}^{\mathrm{c}}<\mathrm{O}^{\mathrm{c}}$ & $\mathrm{t}^{\mathrm{a}}<\mathrm{b}^{\mathrm{b}}<\mathrm{Y}^{\mathrm{b}, \mathrm{c}}<\mathrm{O}^{\mathrm{c}}<\mathrm{W}^{\mathrm{d}}$ & $\mathrm{t}^{\mathrm{a}}<\mathrm{y}^{\mathrm{a}}<\mathrm{b}^{\mathrm{a}}<\mathrm{w}^{\mathrm{b}}<\mathrm{O}^{\mathrm{b}}$ & $\mathrm{y}^{\mathrm{a}}<\mathrm{b}^{\mathrm{b}}<\mathrm{t}^{\mathrm{b}, \mathrm{c}}<\mathrm{O}^{\mathrm{c}, \mathrm{d}}<\mathrm{w}^{\mathrm{d}}$ \\
\hline
\end{tabular}

* $W(w), Y(y), T(t), B(b)$ and $O(o)$, respectively, represent the $\Delta E$ values of different groups using try-in pastes in shades of white, yellow, transparent, bleach and opaque; Capital letters (W, $\mathrm{Y}, \mathrm{T}, \mathrm{B}, \mathrm{O}$ ) mean $2.6 \leq \Delta \mathrm{E}<5.5$; Lowercases ( $\mathrm{W}, \mathrm{y}, \mathrm{t}, \mathrm{b}, \mathrm{o})$ mean $\Delta \mathrm{E}<2.6$; Same superscripts represent no statistical difference between the groups.

Previous studies have found that an increase in zirconia core thickness in bilayered zirconia-based restorations resulted in an increase in $\mathrm{L}^{*}$ values, as well as a decrease in $\mathrm{a}^{*}$ and $\mathrm{b}^{*}$ values and in translucency. ${ }^{32}$ In another study, ${ }^{33} \mathrm{~L}^{*}$ values in high-translucency monolithic zirconia restorations were found to decrease initially when zirconia thickness was reduced, but they tended to be stable when ceramic thickness was further reduced. The change in $\mathrm{L}^{*}$ values was mainly related to the polycrystalline monolayer structure of monolithic zirconia. When its thickness was reduced beneath a certain threshold, the zirconia itself could act as an opaque core and cause internal reflection, which increased, accompanied by a reduction of scattering; this made the $L^{*}$ values relatively stable. Contradictory conclusions have been reported recently: $\mathrm{L}^{*}$ values of translucent monolithic zirconia were found to stabilize when thickness was reduced from $2.0 \mathrm{~mm}$ to $1.5 \mathrm{~mm}$ but increase as thickness was reduced from $1.5 \mathrm{~mm}$ to $1.0 \mathrm{~mm}$ and then again from 1.0 to $0.5 \mathrm{~mm} \cdot{ }^{13}$ In the present study, $\mathrm{L}^{*}$ values did not regularly change along with increases or decreases in zirconia thickness. Moreover, we observed no obvious variation tendency in $\mathrm{a}^{*}$ or $\mathrm{b}^{*}$ parameter values when using different try-in paste shades or substrate colors. The inconsistency of our findings with those of previous studies might be due to the influence of try-in paste shades and substrate color, while those studies aimed to investigate the effect of ceramic thickness on $\mathrm{L}^{*}$ values and therefore used identical substrates.

We found that in addition to its effects on $\mathrm{L}^{*}, \mathrm{a}^{*}$, and $\mathrm{b}^{*}$ values, the thickness of Lava Plus high-translucency zirconia significantly affected its masking ability. According to the Beer-Lambert law, ${ }^{34}$ light absorption is proportional to the thickness of the material through which the light passes. An increase in zirconia thickness allows more light absorp- 
tion; thus, less light reaches the substrate, and the masking ability of zirconia is enhanced. Church ${ }^{19}$ compared four brands of translucent zirconia ceramics and found that for all four, an increase in thickness decreased light transmittance and the influence of substrate color. However, it should be noted that the limited space for tooth reduction poses restrictions on increasing the thickness of the zirconia layer.

As shown in Tables $1-5$, there was a significant difference in $\Delta \mathrm{E}$ values among different shades of try-in paste groups, suggesting that consistency between zirconia shade and resin cement shade might not necessarily provide a final ideal color. If the zirconia shade is within a certain range of deviation from the target color, it is possible to make the esthetic outcome satisfactory by choosing a suitable shade of resin cement. Therefore, it is reasonable to conclude based on this study that changing shades of luting media could be an alternative to increasing the thickness of the Lava Plus high-translucency zirconia layer in order to enhance its masking ability. Chang et al. ${ }^{35}$ evaluated the effects of resin cements in "white opaque," "brown," "yellow," "white," "transparent," and "bleach" shades on the color of hightranslucency zirconia and also found perceptible color differences in the different parts of a restoration. Tabatabaian et al. ${ }^{36}$ compared two high-translucency monolithic-zirconia products with $>40 \%$ transmittance and found that the minimum thickness of such products should be $1.1 \mathrm{~mm}$ in order to achieve ideal masking ability $(\Delta \mathrm{E}<2.6)$ and that a thickness of $0.7-1.1 \mathrm{~mm}$ could achieve a clinically acceptable color difference $(\Delta \mathrm{E}<5.5)$ in masking a discolored tooth in A4 shade. In this study, Lava Plus high-translucency zirconia thicker than $0.7 \mathrm{~mm}$ could achieve clinically acceptable masking $(\Delta \mathrm{E}<5.5)$ of dark teeth (simulated by $5 \mathrm{M} 3$-shade zirconia) with any try-in paste shade, suggesting that Lava Plus had superior masking ability on dark teeth. However, to achieve ideal masking ability $(\Delta \mathrm{E}<2.6)$, it is safest to choose the "transparent" shade of resin cement or make the thickness of zirconia reach $1.2 \mathrm{~mm}$.

By contrast, most of the $0.7-1.5 \mathrm{~mm}$-thick Lava Plus high-translucency zirconia specimens we investigated had poor masking ability on the Co-Cr alloy substrate $(\Delta \mathrm{E}>$ 5.5), and all of the $0.7-1.5 \mathrm{~mm}$ specimens in all shades failed to achieve ideal masking ability $(\Delta \mathrm{E}<2.6)$. Only when ceramic thickness reached $1.5 \mathrm{~mm}$ could certain shades of zirconia specimen (2M1, 2M3, 3M2, 4M2 and $5 \mathrm{M} 2)$ achieve clinically acceptable color differences $(\Delta \mathrm{E}<$ 5.5) regardless of try-in paste shade. Even when their thickness reached $1.5 \mathrm{~mm}$, the masking ability of the $1 \mathrm{M} 2$ - and 2M2-shade zirconia specimens on the Co-Cr alloy substrate was not clinically acceptable $(\Delta \mathrm{E}<5.5)$, no matter which shade of try-in paste was chosen. This suggested that when the target final color was either 1M2 or 2M2, Lava Plus high-translucency zirconia would not be suitable for masking a Co-Cr alloy post-core. When we sintered a layer of opaque porcelain onto the Co-Cr alloy substrate, zirconia specimens of $1.2-1.5 \mathrm{~mm}$ thickness in all 8 shades achieved clinically acceptable color differences $(\Delta \mathrm{E}<5.5)$ with any try-in paste shade, and the 0.7-1.0 mm zirconia specimens in most shades achieved clinically acceptable color differences $(\Delta \mathrm{E}<5.5)$ when suitable shades of try-in paste were chosen. However, our findings also suggested that when zirconia thickness reached $1.5 \mathrm{~mm}$, both a suitable choice of resin cement shade and presintering opaque porcelain onto the $\mathrm{Co}-\mathrm{Cr}$ alloy surface were necessary to achieve $\Delta \mathrm{E}$ values $<2.6$ for 7 shades of zirconia (excepting 1M1).

Lava Plus high-translucency zirconia specimens showed much better masking ability on the precious-metal substrate, because a zirconia layer thicker than $0.7 \mathrm{~mm}$ could achieve clinically acceptable masking ability $(\Delta \mathrm{E}<5.5)$ with any of the try-in paste shades. Furthermore, zirconia specimens thicker than $0.7 \mathrm{~mm}$ in most shades could achieve ideal masking ability $(\Delta \mathrm{E}<2.6)$ with the selection of suitable shades of try-in paste. Unlike with the Co-Cr alloy substrate, sintering a layer of opaque porcelain onto the precious-metal substrate did not necessarily enhance the masking ability of Lava Plus high-translucency zirconia, suggesting that a prior sintering of opaque porcelain was unnecessary for restoring a precious-metal post-core.

It should be noted that we used five typical shades of tryin paste, instead of all shades available on the market, in this study. Other shades and brands of resin cement are also commercially available. Although different manufacturers might name the specific shades of try-in paste differently, most shades would be covered by the five we studied. Therefore, the results of this study could provide a valuable guidance for choosing resin cement shades in clinical practice.

\section{CONCLUSION}

Unexpectedly, resin cements in "opaque" or "bleach" shades were not the best choices for luting high-translucency monolithic zirconia to mask the discolored substrates. Due to the limitations of this study and the materials used, the null hypothesis was accepted and the following conclusions are warranted to be drawn: choosing suitable resin cement shades allowed Lava Plus high-translucency monolithic zirconia in thickness of $0.7-1.5 \mathrm{~mm}$ to achieve ideal masking ability $(\Delta \mathrm{E}<2.6)$ on the dark-tooth (simulated by $5 \mathrm{M} 3$ shade of zirconia). Not all shades of $0.7-1.5-\mathrm{mm}$ Lava Plus high-translucency monolithic zirconia could achieve clinically acceptable masking ability $(\Delta \mathrm{E}<5.5)$ on the Co-Cr alloy post-core, no matter which shade of resin cement was selected. We recommend sintering a layer of opaque porcelain onto the surface of the Co-Cr alloy, choosing a suitable resin cement shade, and increasing the thickness of the zirconia restoration beyond $1.0 \mathrm{~mm}$ to achieve clinically acceptable masking ability. Choosing suitable shades of resin cements allowed Lava Plus high-translucency monolithic zirconia at thicknesses of $0.7-1.5 \mathrm{~mm}$ to achieve ideal masking ability $(\Delta \mathrm{E}<2.6)$ on a precious-metal post-core. Sintering opaque porcelain onto a precious-metal surface prior to luting zirconia restorations should be unnecessary. 


\section{ACKNOWLEDGEMENTS}

The authors thank Mrs. Min Li and Mei He (LZJ Dental Lab, Shen Zhen, China) for providing and manufacturing $\mathrm{Lava}^{\mathrm{TM}}$ Plus high translucent zirconia.

\section{ORCID}

Shiqi Dai https://orcid.org/0000-0002-9959-8625

Chen Chen https://orcid.org/0000-0002-2989-180X

Mo Tang bttps://orcid.org/0000-0002-2869-4556

Ying Chen bttps:// orcid.org/0000-0002-5462-0366

Lu Yang https://orcid.org/0000-0002-7127-9091

He Feng https://orcid.org/0000-0003-0852-7328

Bingzhuo Chen https://orcid.org/0000-0001-9630-5412

Haifeng Xie https://orcid.org/0000-0003-2008-3846

\section{REFERENCES}

1. Tabatabaian F, Bakhshaei D, Namdari M. Effect of Resin Cement Brand on the Color of Zirconia-Based Restorations. J Prosthodont 2018 Jul 20.

2. Miyazaki T, Nakamura T, Matsumura H, Ban S, Kobayashi T. Current status of zirconia restoration. J Prosthodont Res 2013;57:236-61.

3. Lee YK. Translucency of dental ceramic, post and bracket. Materials (Basel) 2015;8:7241-9.

4. Salas M, Lucena C, Herrera LJ, Yebra A, Della Bona A, Pérez MM. Translucency thresholds for dental materials. Dent Mater 2018;34:1168-74.

5. Baldissara P, Wandscher VF, Marchionatti AME, Parisi C, Monaco C, Ciocca L. Translucency of IPS e.max and cubic zirconia monolithic crowns. J Prosthet Dent 2018;120:269-75.

6. Stefanescu C, Ionita C, Nechita V, Drafta S, Oancea L, Petre A. Survival rates and complications for zirconia-based fixed dental prostheses in a period up to 10 years: A systematic review. Eur J Prosthodont Restor Dent 2018;26:54-61.

7. Silva LHD, Lima E, Miranda RBP, Favero SS, Lohbauer U, Cesar PF. Dental ceramics: a review of new materials and processing methods. Braz Oral Res 2017;31:e58.

8. Aktas G, Sahin E, Vallittu P, Ozcan M, Lassila L. Effect of colouring green stage zirconia on the adhesion of veneering ceramics with different thermal expansion coefficients. Int J Oral Sci 2013;5:236-41.

9. Ghodsi S, Jafarian Z. A review on translucent zirconia. Eur J Prosthodont Restor Dent 2018;26:62-74.

10. Matsuzaki F, Sekine H, Honma S, Takanashi T, Furuya K, Yajima Y, Yoshinari M. Translucency and flexural strength of monolithic translucent zirconia and porcelain-layered zirconia. Dent Mater J 2015;34:910-7.

11. Al Hamad KQ, Obaidat II, Baba NZ. The effect of ceramic type and background color on shade reproducibility of all-ceramic restorations. J Prosthodont 2018 Dec 7.

12. Tabatabaian F, Masoomi F, Namdari M, Mahshid M. Effect of three different core materials on masking ability of a zirconia ceramic. J Dent (Tehran) 2016;13:340-8.

13. Giti R, Hojati SA. Effect of varying thickness and number of coloring liquid applications on the color of anatomic contour monolithic zirconia ceramics. J Dent (Shiraz) 2018;19:311-9.

14. Tabatabaian F, Shabani S, Namdari M, Sadeghpour K. Masking ability of a zirconia ceramic on composite resin substrate shades. Dent Res J (Isfahan) 2017;14:389-94.

15. Sakai T, Sato T, Hisanaga R, Shinya A, Takemoto S, Yoshinari M. Optical properties and flexural strength of translucent zirconia layered with high-translucent zirconia. Dent Mater J 2019;38:368-77.

16. Suputtamongkol K, Tulapornchai C, Mamani J, Kamchatphai W, Thongpun N. Effect of the shades of background substructures on the overall color of zirconia-based all-ceramic crowns. J Adv Prosthodont 2013;5:319-25.

17. Vichi A, Ferrari M, Davidson CL. Influence of ceramic and cement thickness on the masking of various types of opaque posts. J Prosthet Dent 2000;83:412-7.

18. Brewer JD, Akers CK, Garlapo DA, Sorensen SE. Spectrometric analysis of the influence of metal substrates on the color of metal-ceramic restorations. J Dent Res 1985;64:74-7.

19. Church TD, Jessup JP, Guillory VL, Vandewalle KS. Translucency and strength of high-translucency monolithic zirconium oxide materials. Gen Dent 2017;65:48-52.

20. Wang F, Takahashi H, Iwasaki N. Translucency of dental ceramics with different thicknesses. J Prosthet Dent 2013;110:14-20.

21. Bacchi A, Boccardi S, Alessandretti R, Pereira GKR. Substrate masking ability of bilayer and monolithic ceramics used for complete crowns and the effect of association with an opaque resin-based luting agent. J Prosthodont Res 2019;63:321-6.

22. Piwowarczyk A, Lauer HC, Sorensen JA. The shear bond strength between luting cements and zirconia ceramics after two pre-treatments. Oper Dent 2005;30:382-8.

23. Dede DÖ, Sahin O, Özdemir OS, Yilmaz B, Celik E, Köroğlu A. Influence of the color of composite resin foundation and luting cement on the final color of lithium disilicate ceramic systems. J Prosthet Dent 2017;117:138-43.

24. Pires LA, Novais PM, Araújo VD, Pegoraro LF. Effects of the type and thickness of ceramic, substrate, and cement on the optical color of a lithium disilicate ceramic. J Prosthet Dent 2017;117:144-9.

25. Xing W, Chen X, Ren D, Zhan K, Wang Y. The effect of ceramic thickness and resin cement shades on the color matching of ceramic veneers in discolored teeth. Odontology 2017; 105:460-6.

26. Dede DÖ, Ceylan G, Yilmaz B. Effect of brand and shade of resin cements on the final color of lithium disilicate ceramic. J Prosthet Dent 2017;117:539-44.

27. Sproull RC. Color matching in dentistry. II. Practical applications of the organization of color. J Prosthet Dent 1973;29:55666.

28. Tabatabaian F. Color in zirconia-based restorations and related factors: A literature review. J Prosthodont 2018;27:201-11.

29. Ragain JC Jr, Johnston WM. Color acceptance of direct dental restorative materials by human observers. Color Res Appl 2000;25:278-85.

30. Douglas RD, Steinhauer TJ, Wee AG. Intraoral determination of the tolerance of dentists for perceptibility and acceptabili- 
ty of shade mismatch. J Prosthet Dent 2007;97:200-8.

31. Ruyter IE, Nilner K, Moller B. Color stability of dental composite resin materials for crown and bridge veneers. Dent Mater 1987;3:246-51.

32. Sinmazisik G, Demirbas B, Tarcin B. Influence of dentin and core porcelain thickness on the color of fully sintered zirconia ceramic restorations. J Prosthet Dent 2014;111:142-9.

33. Kim HK, Kim SH, Lee JB, Han JS, Yeo IS, Ha SR. Effect of the amount of thickness reduction on color and translucency of dental monolithic zirconia ceramics. J Adv Prosthodont 2016;8:37-42.

34. Ilie N, Stawarczyk B. Quantification of the amount of light passing through zirconia: the effect of material shade, thickness, and curing conditions. J Dent 2014;42:684-90.

35. Chang J, Da Silva JD, Sakai M, Kristiansen J, Ishikawa-Nagai S. The optical effect of composite luting cement on all ceramic crowns. J Dent 2009;37:937-43.

36. Tabatabaian F, Motamedi E, Sahabi M, Torabzadeh H, Namdari M. Effect of thickness of monolithic zirconia ceramic on final color. J Prosthet Dent 2018;120:257-62. 